\title{
Proteolytic and proteomic changes in milk at quarter level following infusion with Escherichia coli lipopolysaccharide
}

\author{
K. Hinz, ${ }^{\star}$ L. B. Larsen, † O. Wellnitz,‡ R. M. Bruckmaier,‡ and A. L. Kelly ${ }^{\star 1}$ \\ *School of Food and Nutritional Sciences, University College Cork, Co. Cork, Ireland \\ †Department of Food Science, Aarhus University, DK-8830 Tjele, Denmark \\ $\ddagger$ Veterinary Physiology, Vetsuisse Faculty, University of Bern, CH-3001 Switzerland
}

\section{ABSTRACT}

Mastitis is a major disease in dairy cattle, which causes significant economic losses due to decreased milk production, veterinary costs, and discarded milk. Escherichia coli is one of the most prevalent species of gram-negative bacteria that induce clinical mastitis. The objective of the present study was to characterize the proteolytic and proteomic changes in milk in response to infusion with lipopolysaccharide (LPS) at quarter level in a model mastitis system. One quarter of each of 2 cows was infused with 0.1 or $5 \mu \mathrm{g}$ of LPS. The somatic cell count of the infused quarters reached a peak $6 \mathrm{~h}$ after infusion to a greater extent in the cow infused with $5 \mu \mathrm{g}$ of LPS and changes in plasmin activity in milk differed between the 2 animals. Urea-polyacrylamide gel electrophoretograms of milk samples of the cow infused with $5 \mu \mathrm{g}$ of LPS obtained at different time points after infusion and incubated for up to 7 $\mathrm{d}$ showed almost full hydrolysis of $\beta$ - and $\alpha_{\mathrm{s} 1}$-casein during incubation of milk samples due to indigenous proteolytic activity. Two-dimensional gel electrophoretograms of milk at 0,6 , or $12 \mathrm{~h}$ after infusion with LPS showed hydrolysis of $\alpha_{\mathrm{s}}$-casein and $\beta$-casein as well as the appearance of lower molecular weight products. Eleven fragments from proteolysis of the caseins were identified by matrix-assisted laser desorption/ionization time-of-flight mass spectrometry and, in addition, proteolysis patterns of casein by the indigenous bovine milk proteases plasmin and cathepsin D were studied in model studies using 2-dimensional gel electrophoretograms. Twelve hours after infusion, lower abundance markers of inflammation were identified, including serotransferrin, fibrinogen $\beta$ chain, protein S100 A12, and the antimicrobial polypeptide cathelicidin.

Key words: coliform mastitis, matrix-assisted laser desorption/ionization time-of-flight mass spectrometry, 2-dimensional gel electrophoretogram, proteolysis

Received August 9, 2011.

Accepted December 5, 2011.

${ }^{1}$ Corresponding author: a.kelly@ucc.ie

\section{INTRODUCTION}

It is well known and documented that proteolysis increases in bovine milk at elevated SCC (e.g., in mastitis; de Rham and Andrews, 1982; Andrews, 1983; Le Roux et al., 1995; Moussaoui et al., 2004). This increase in proteolysis is mainly due to an increase in the level of proteases present in the milk (Larsen et al., 2006), as well as increased activation of protease zymogens, leading to increased enzymatic activities (e.g., as observed for the plasminogen system in milk; Heegaard et al., 1994).

The proteases in milk may potentially arise from different sources; they can be secreted into milk from the mammary epithelium, be transferred from blood to milk, particularly in cases of a compromised barrier between milk and blood in mastitis, or be secreted or leaked from invading microorganisms or bovine somatic cells, or both (Politis et al., 1989; Haddadi et al., 2006; Larsen et al., 2006). Furthermore, some bacteria secrete activators of protease zymogens, which, in synergy with bovine proenzymes, can increase the proteolytic potential of fresh and stored milk (Jackson et al., 1981; Leigh, 1999; Larsen et al., 2006). Depending on the proteolytic enzyme, different secretion pathways can be expected to be prevalent; plasmin, the principal protease in normal milk with low SCC, is transported into milk from blood in its zymogen form, plasminogen. Both neutrophils and macrophages contain active lysosomal acid and neutral proteases and protease zymogens, such as cathepsins, procathepsins, and elastase (Kirschke and Barrett, 1987; Travis, 1988; Sordillo et al., 1997; Kelly et al., 2006). Knowledge of the proteases responsible for proteolysis in milk is important, as it enables the identification of the enzyme systems that are most detrimental to the protein quality in milk. Generally, hydrolysis of proteins in raw milk is undesirable (e.g., through negative effects on cheese yield; Auldist and Hubble, 1998), although proteolysis is beneficial in some dairy products, like cheese, where proteolysis can contribute to the ripening process (Wium et al., 1998; Hurley et al., 2000; Gagnaire et al., 2001). 
In addition to characterization of proteases and measurement of enzyme activities, new peptidomic methods using proteomic tools and mass spectrometry are now available, by which the actual result of these proteolytic activities in specific milk samples can be studied and characterized. In a recent study, 1 quarter of each of 2 cows was infused with lipoteichoic acid from Staphylococcus aureus (Larsen et al., 2010).

The objective of this study was to analyze the peptide products of proteolysis in the model mastitis system. Twenty different peptide products were obtained and characterized and the proteases responsible were identified. The peptides obtained were shown to have been derived from $\alpha_{\mathrm{s} 1^{-}}$and $\beta-\mathrm{CN}$. On the basis of the peptide cleavage sites, it was possible to propose that the possible proteases responsible for the proteolysis were plasmin, cathepsin $\mathrm{B}$ and $\mathrm{D}$, elastase, and aminoand carboxypeptidases.

Dairy producers are particularly concerned with mastitis infections arising from gram-negative bacteria because 1) it has been established that coliform pathogens are not successfully treated with antimicrobial drugs and other traditional remedies (Shim et al., 2004), 2) a coliform treatment vaccine has had limited effectiveness (Hogan et al., 1992), and 3) typically, a loss of up to $25 \%$ of the cows infected with gram-negative mastitis occurs as a result of culling or death because of complications due to the infection (Eberhart et al., 1987). These serious consequences of a coliform mastitis infection for dairy producers and the difficulties of counteracting it have led to much research in the field (Hirvonen et al., 1999; Bannerman et al., 2003, 2004).

Escherichia coli strains have frequently been used to experimentally induce mastitis infection in research animals because $E$. coli is the most common gramnegative bacterium to cause mastitis in cows (Andrews, 1983; Hirvonen et al., 1999; Moussaoui et al., 2002; Sládek et al., 2002; Bannerman et al., 2004; Moussaoui et al., 2004; Schmitz et al., 2004; Sohn et al., 2007). The present study is a further development of this approach and reports a proteomic and peptidomic study of bovine milk from 2 cows during early immunological response to infusion with LPS from the cell walls of the gram-negative E. coli (Schalm and Ziv-Silberman, 1968; Moussaoui et al. 2002; Strandberg et al. 2005; Haddadi et al., 2006), but it eliminates the contribution from mastitis bacteria themselves to the proteolytic cascade.

\section{MATERIALS AND METHODS}

\section{Sample Preparation}

Immediately after the morning milking, 2 dairy cows were infused in one quarter with $0.1 \mu \mathrm{g}$ or $5 \mu \mathrm{g}$ of LPS from E. coli that caused mastitis (Yang et al., 2008), diluted in $10 \mathrm{~mL}$ of saline $(9 \mathrm{~g} / \mathrm{L})$. One control quarter received only saline. Milk samples $(300 \mathrm{~mL})$ were collected from the gland to be infused and from the control gland before infusion $(t=0)$, and $6,12,48$, and $144 \mathrm{~h}$ after infusion; samples were obtained by hand milking during routine milking procedures. Somatic cell count measurements were performed with a DeLaval cell counter (DeLaval International AB, Tumba, Sweden). Whole milk samples were skimmed as described by Larsen et al. (2010).

\section{Determination of Plasmin Activity and Assessment of Proteolysis During Storage}

Plasmin activity was performed as described by Larsen et al. (2010) and expressed in amino methyl coumarin (AMC) units (nanomoles of AMC released per minute) $/ \mathrm{mL}$ of milk. Milk samples were incubated at $37^{\circ} \mathrm{C}$ for $0,1,3$, or $7 \mathrm{~d}$, with sodium azide $(0.5$ $\mathrm{g} / \mathrm{L})$ to prevent microbial growth. Milk samples were taken at each time point. Urea PAGE of stored milk samples was then performed as described by Larsen et al. (2010). Gels were then scanned using a GS-800 calibrated densitometer (Bio-Rad Laboratories Inc., Hercules, CA).

\section{Model Studies with Indigenous Milk Enzymes}

Casein (Sigma-Aldrich, St. Louis, MO) was dissolved by stirring overnight at room temperature $\left(20^{\circ} \mathrm{C}\right)$ at $10 \mathrm{mg} / \mathrm{mL}$ in $0.05 \mathrm{M}$ phosphate buffer and $0.035 \mathrm{M}$ $\mathrm{NaCl}$ at $\mathrm{pH}$ 6.8. Bovine plasminogen (Sigma-Aldrich) or bovine cathepsin D (Sigma-Aldrich) were added at $t=0$ at enzyme to substrate ratios of $1 / 100 \mathrm{wt} / \mathrm{wt}$. Plasminogen was activated with urokinase (Calbiochem/VWR, Herlev, Denmark) before addition to the samples as described by Larsen et al. (2004). After addition of enzymes, the samples were incubated at $37^{\circ} \mathrm{C}$, and samples were drawn after 6,24 , and $36 \mathrm{~h}$. Three parallel incubations were carried out: A) control with no enzyme addition, B) with activated plasminogen, and $\mathrm{C}$ ) with cathepsin D. All experiments were carried out in triplicate in parallel incubations of enzymes added to aliquots of the stock substrate solution.

\section{Proteomic Analysis}

Skim milk samples were analyzed by 2-dimensional gel electrophoresis (2-DE) essentially as described by Larsen et al. (2010). The first dimension of protein separation was carried out on immobilized 11-cm IPG strips $(\mathrm{pH} 4-7)$, and $7.5 \times 11-\mathrm{cm} 8$ to $16 \%$ gradient criterion gels were used for the second dimension (Bio-Rad 
Table 1. Somatic cell count (thousands of cells per milliliter) of milk samples from cows infused with a high (HLPS) or low (LLPS) level of LPS (time indicates hours after infusion with LPS)

\begin{tabular}{lcccc}
\hline $\begin{array}{l}\text { Time after } \\
\text { infusion }(\mathrm{h})\end{array}$ & $\begin{array}{c}\text { LLPS } \\
\text { control }\end{array}$ & $\begin{array}{c}\text { LLPS } \\
\text { infused }\end{array}$ & $\begin{array}{c}\text { HLPS } \\
\text { control }\end{array}$ & $\begin{array}{c}\text { HLPS } \\
\text { infused }\end{array}$ \\
\hline 0 & 36 & 31 & 90 & 243 \\
6 & - & 1,706 & - & 3,814 \\
12 & - & 517 & -56 & 3,135 \\
24 & 102 & 118 & - & 3,821 \\
48 & - & 160 & & 3,944 \\
\hline
\end{tabular}

Laboratories Inc.). A volume (185 $\mu \mathrm{L})$ corresponding to $300 \mu \mathrm{g}$ of milk protein sample was applied to each gel according to the Bradford assay. For the studies of milk samples from LPS-infused cows, the gels were stained with colloidal Coomassie Brilliant Blue (CBB) G-250 (SERVA Electrophoresis GmbH, Heidelberg, Germany) as described by Larsen et al. (2010), whereas the gels used in the model study were silver stained (Wedholm et al., 2008b). The 2-DE gels were photographed using a Vilber Lourmat digital camera (Image House A/S, Copenhagen, Denmark) equipped with Gel-Pro Analyzer software (Media Cybernetics Inc., Bethesda, MD). Protein spots of significance were subjected to in-gel digestion by addition of trypsin and identified by peptide mass fingerprinting (PMF) using matrix-assisted laser desorption/ionization time-of-flight mass spectrometry (MALDI-TOF MS) essentially as described earlier (Larsen et al., 2010). Custom-made chromatographic columns were used for desalting and concentration of the peptide mixture before mass spectrometric analysis. The peptides were eluted in $0.5 \mu \mathrm{L}$ of matrix solution (15-20 g/L of $\alpha$-cyano-4-hydroxycinnamic acid in 70\% acetonitrile; Sigma-Aldrich) directly onto the MALDI target plate (Bruker Daltonik GmbH, Bremen, Germany). Mass spectra were obtained by PMF using an Ultraflex MALDI-TOF tandem mass spectrometer (Bruker Daltonik GmbH) in reflection mode. Proteins were identified by PMF mass searches in the database Swiss Prot (Swiss Institute of Bioinformatics, Geneva, Switzerland) followed by mass searches in the database using the ion search program Mascot (Matrix Science Inc., Boston, MA). In this program, the experimental mass value obtained from MS is compared with calculated peptide masses from a database. A scoring algorithm is used to identify the closest match. Significant protein identifications (protein scores above 62, $P<$ $0.05)$ were reported and manually verified.

\section{RESULTS}

\section{SCC and Plasmin Activity After Infusion}

The SCC of milk from the control and infused quarters of the cow infused with low LPS concentration (LLPS) and the cow infused with high LPS concentration (HLPS) are shown in Table 1. Both cows had normal initial levels expected for healthy animals, but showed a very large increase in SCC within $6 \mathrm{~h}$ of infusion, to a greater extent in cow with HLPS than in the case of LLPS. In the sample taken $48 \mathrm{~h}$ following infusion, the SCC for both cows was still higher than the original level, again to a greater extent in the cow with HLPS than in the cow with LLPS.

Changes in plasmin activity in milk differed between the 2 animals; the activity in milk from the infused quarter after $0 \mathrm{~h}$ of infusion with LPS was higher in the LLPS cow than in the HLPS cow (Table 2). However, milk from the HLPS cow showed higher plasmin activity $6 \mathrm{~h}$ after infusion than milk from the LLPS cow.

\section{Electrophoretic Studies of Proteolysis}

The proteolysis patterns in milk samples from 2 cows infused with HLPS or LLPS incubated for up to $7 \mathrm{~d}$

Table 2. Plasmin activity [nmol of amino methyl coumarin (AMC) released per minute per milliliter of milk] of milk samples from cows infused with a high (HLPS) or low (LLPS) level of LPS (time indicates hours after infusion with LPS) at $37^{\circ} \mathrm{C}$ for up to $7 \mathrm{~d}$

\begin{tabular}{llllll}
\hline & \multicolumn{2}{c}{ LLPS } & & \multicolumn{2}{c}{ HLPS } \\
\cline { 2 - 3 } \cline { 5 - 6 } $\begin{array}{l}\text { Time after } \\
\text { infusion }(\mathrm{h})\end{array}$ & $\mathrm{d} 0$ & $\mathrm{~d} 7$ & & $\mathrm{~d} 0$ & $\mathrm{~d} 7$ \\
\hline $\begin{array}{l}\text { Control } \\
\quad\end{array}$ & 0.0144 & 0.0325 & & 0.0500 & 0.0247 \\
$\begin{array}{l}\text { Infused } \\
\quad\end{array}$ & & & & 0.0076 & 0.0135 \\
6 & 0.0105 & 0.0055 & & 0.0465 & 0.0301 \\
\hline
\end{tabular}




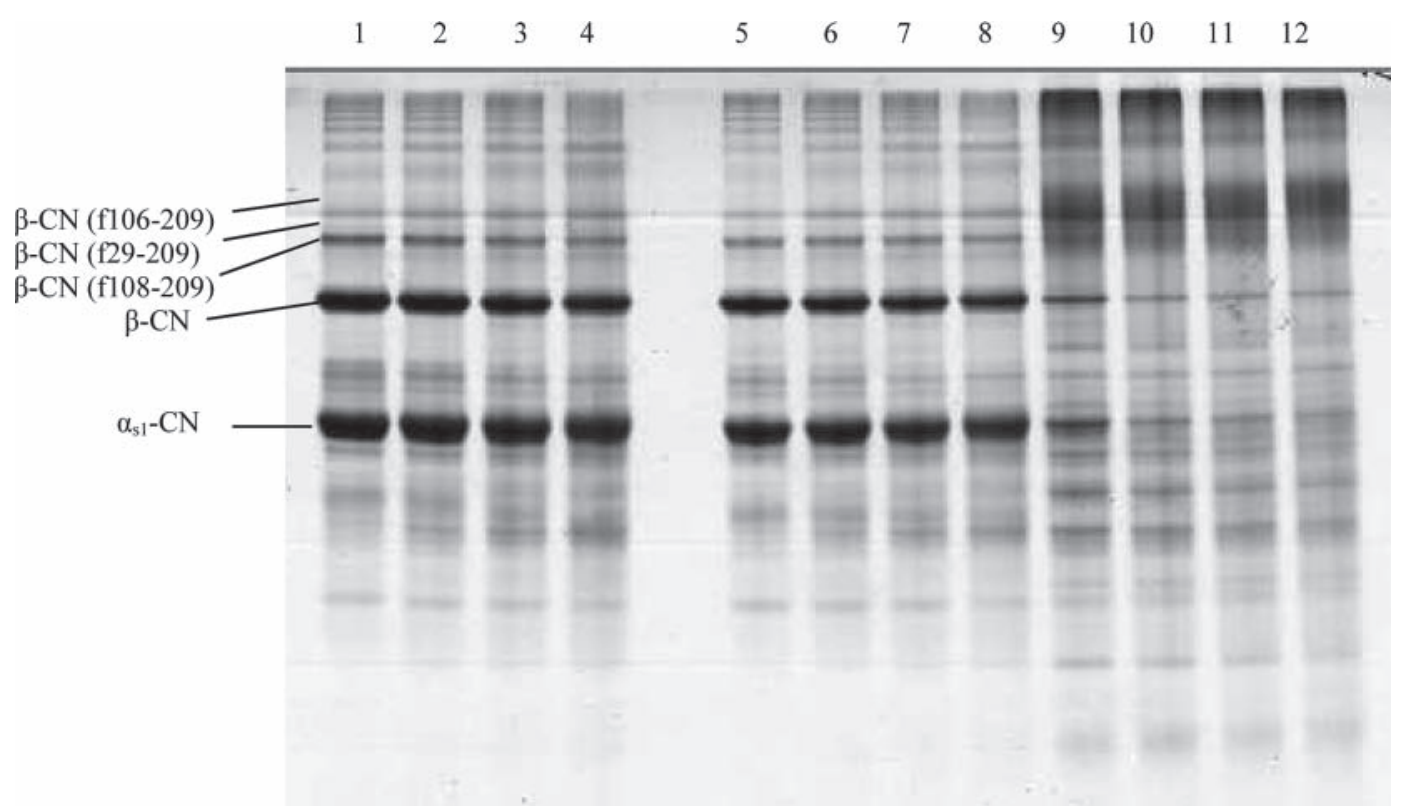

Figure 1. Urea-PAGE electrophoretograms of milk from the control and infused quarters of a cow infused with $5 \mu \mathrm{g}$ of LPS (high LPS concentration, HLPS) and sampled after 0 and $6 \mathrm{~h}$, and then incubated for $0,1,3$, or $7 \mathrm{~d}$ at $37^{\circ} \mathrm{C}$. Lane $1-4$ : control sample, incubated at $37^{\circ} \mathrm{C}$ for 0 (lane 1), 1 (lane 2), 3 (lane 3), or 7 (lane 4) d; lane 5-8: 0-h infused quarter sample, incubated at $37^{\circ} \mathrm{C}$ for 0 (lane 5), 1 (lane 6 ), 3 (lane 7 ), or 7 (lane 8) d; lane 9-12: 6-h infused quarter sample, incubated at $37^{\circ} \mathrm{C}$ for 0 (lane 9), 1 (lane 10), 3 (lane 11), or 7 (lane 12) d.

at $37^{\circ} \mathrm{C}$ were initially studied using urea PAGE. Electrophoretograms of the milk samples from the HLPSinfused quarter of one cow after $6 \mathrm{~h}$ showed a very significant increase in overall proteolysis over incubation (Figure 1, lane 9-12). Urea PAGE patterns for the control milk sample (i.e., milk from the uninfused quarter) of the cow with HLPS showed little hydrolysis of the caseins over incubation (Figure 1, lane 1-4). Samples taken $0 \mathrm{~h}$ after infusion also showed only slow hydrolysis, mainly of $\beta$-CN over incubation. However, samples taken $6 \mathrm{~h}$ after infusion showed almost complete hydrolysis of $\beta$-and $\alpha_{\mathrm{s} 1}$-CN within $1 \mathrm{~d}$ of incubation (Figure 1).

The urea PAGE patterns of the control milk sample (i.e., milk from the uninfused quarter) of the cow with LLPS also showed only little hydrolysis of $\beta-\mathrm{CN}$ and no hydrolysis of $\alpha_{\mathrm{s} 1}$-CN over incubation. Samples taken immediately $(0 \mathrm{~h})$ after infusion also showed only little hydrolysis after $7 \mathrm{~d}$ of incubation at $37^{\circ} \mathrm{C}$ (Figure 2). However, electrophoretograms of the milk samples infused with LLPS after $6 \mathrm{~h}$ showed almost complete hydrolysis of $\beta$ - and $\alpha_{\mathrm{s} 1}$ - $\mathrm{CN}$ after $7 \mathrm{~d}$ of incubation but the breakdown was not as significant as in milk from the cow treated with HLPS (Figure 1), as can be seen by the lower amount of $\beta$-CN-derived fragments appearing on the gel.

The protein patterns in the control and infused quarter samples from a cow with LLPS (not shown) and a cow with HLPS (control quarter, quarter infused after 0,6 , or $12 \mathrm{~h}$ ) were further analyzed by 2 -DE and spots were identified by PMF using MALDI-TOF MS. Representative gels from milk samples from a control quarter and the infused quarter after 0,6 , and $12 \mathrm{~h}$ were chosen to illustrate the protein profiles generated in the present study (Figures $3 \mathrm{~A}$ and $3 \mathrm{~B}$ and Figures $4 \mathrm{~A}$ and $4 \mathrm{~B})$. The resulting protein map from the control quarter $0 \mathrm{~h}$ after infusion and the infused quarter after $0 \mathrm{~h}$ (Figures 3A and 3B) exhibited an abundance of casein proteins including $\alpha_{\mathrm{s} 1}-\mathrm{CN}, \beta-\mathrm{CN}$, and $\kappa-\mathrm{CN}$ variants, and the whey proteins BSA, $\beta-\mathrm{LG}$, and $\alpha-\mathrm{LA}$.

In contrast, the protein pattern of the infused quarter after $6 \mathrm{~h}$ (Figure 4A) and after $12 \mathrm{~h}$ (Figure 4B) showed a decreased abundance of $\alpha_{\mathrm{S}_{1}} \mathrm{CN}$ and $\beta-\mathrm{CN}$ but a marked increase in BSA. $\kappa$-Casein spots were still evident in the infused quarters after 6 or $12 \mathrm{~h}$ but in decreased amounts. Marked changes in the protein profiles of milk from infused quarters included several new spots appearing in the lower isoelectric point $(\mathbf{p I})$ range and with lower molecular mass than the intact casein, in addition to several additional new spots with higher $\mathrm{pI}$ values, with various masses, both below and above the masses of the caseins (Figure $4 \mathrm{~A}$ and B).

Mass spectrometry identifications of 26 spots analyzed are shown in Table 3. Of these, half of the proteins identified corresponded to $\alpha_{\mathrm{s} 1^{-}}$or $\alpha_{\mathrm{s} 2^{-}} \mathrm{CN}$. Eight spots were identified as $\alpha_{\mathrm{s} 1^{-}} \mathrm{CN}$ isoforms with apparent molecular masses from 18.0 to $27.0 \mathrm{kDa}$ and apparent pI from 4.2 to $4.3 ; 4$ spots were identified as $\alpha_{\mathrm{s} 2}$ - $\mathrm{CN}$ 


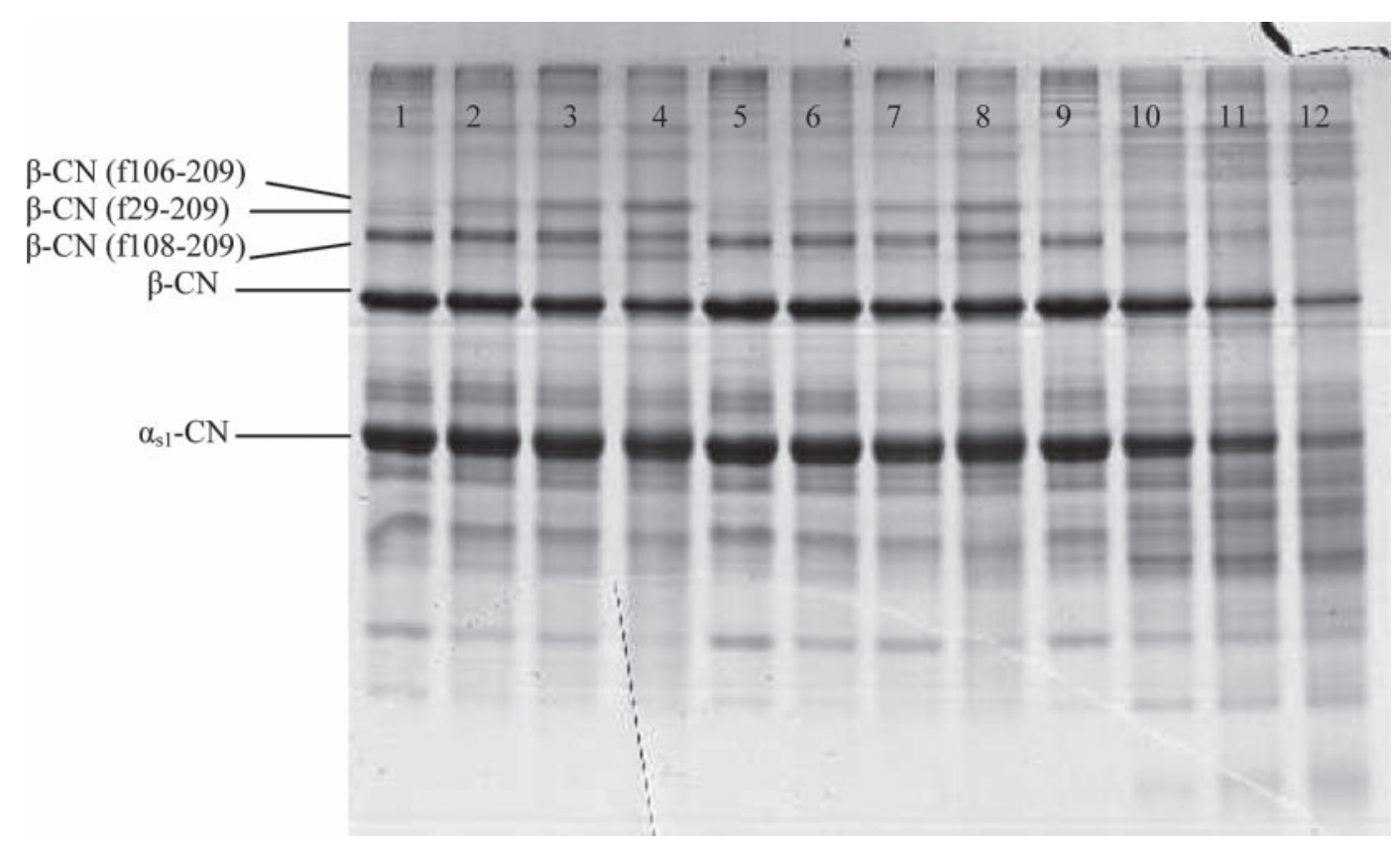

Figure 2. Urea-PAGE electrophoretograms of milk from the control and infused quarters of a cow infused with $0.1 \mu \mathrm{g}$ of LPS (low LPS concentration, LLPS) and sampled after 0 and $6 \mathrm{~h}$, and then incubated for $0,1,3$, or $7 \mathrm{~d}$ at $37^{\circ} \mathrm{C}$. Lane $1-4$ : control sample, incubated at $37^{\circ} \mathrm{C}$ for 0 (lane 1), 1 (lane 2), 3 (lane 3), or 7 (lane 4) d; lane 5-8: 0-h infused quarter sample, incubated at $37^{\circ} \mathrm{C}$ for 0 (lane 5 ), 1 (lane 6), 3 (lane 7 ), or 7 (lane 8) d; lane 9-12: 6-h infused quarter sample, incubated at $37^{\circ} \mathrm{C}$ for 0 (lane 9), 1 (lane 10), 3 (lane 11), or 7 (lane 12) d.

isoforms (22.0-23.0 kDa, pI of 5.3-5.4). Most of these isoforms corresponded to breakdown products, presumably originating from the action of indigenous bovine proteolytic enzymes, producing several peptides with different molecular masses and $\mathrm{pI}$ values. Together with these 2 main groups of casein-derived spots, BSA (4 spots) was identified as well as some highly abundant proteins including serotransferrin (2 spots), vitamin Dbinding protein, cytoplasmic actin (4 spots), and the $\beta$ chain of fibrinogen (1 spot). Additional proteins were identified in the lower mass region and higher pI area, such as protein S100-A12, and 2 antimicrobial peptides (AMP) in the cathelicidin family.

To further study by 2-DE the breakdown patterns of caseins by indigenous bovine milk proteases, a model study of proteolysis by such proteases was conducted. Casein from bovine milk was dissolved at normal milk $\mathrm{pH}$ (6.8) and hydrolyzed with the bovine milk proteases plasmin (in the form of activated bovine plasminogen due to limited shelf life stability of the plasmin enzyme itself) or bovine cathepsin $\mathrm{D}$. The progress in proteolysis after 6 and $24 \mathrm{~h}$ by plasmin is shown, together with the result of digestion with cathepsin D after 24 $\mathrm{h}$ (Figure $5 \mathrm{~A}-\mathrm{D})$. In the case of hydrolysis by plasmin, breakdown of $\alpha_{\mathrm{s}}$-and $\beta$-CN was evident after $6 \mathrm{~h}$ of incubation at $37^{\circ} \mathrm{C}$, with a range of new spots in both the $\alpha_{\mathrm{s} 1}-\mathrm{CN}$ product area (box in Figure 5) and at higher pI values. This hydrolysis was observed to progress by time, and extensive breakdown of $\alpha_{\mathrm{s}}$-and $\beta-\mathrm{CN}$, and to some extent also $\mathrm{\kappa}$-CN, was evident after $24 \mathrm{~h}$, when new spots as a result of plasmin-induced hydrolysis were apparent just below the $\kappa-\mathrm{CN}$ train of spots in the higher pI range, in addition to a large amount of further hydrolysis products (Figures $5 \mathrm{~B}$ and $5 \mathrm{C}$ ). In the case of cathepsin $\mathrm{D}$, extensive cleavage of $\alpha_{\mathrm{s} 1}$-CN into larger, well-defined fragments (box in Figure 5D) was evident and $\kappa-\mathrm{CN}$ was also clearly hydrolyzed.

\section{DISCUSSION}

Mammary tissue is permeated with neutrophils and lymphocytes that, together with immune-cell-secreted cytokines, chemokines, and other cell defense mechanisms, can attack invading bacteria, including mastitis infections (Bannerman et al., 2003). Lipopolysaccharide from gram-negative $E$. coli has been used in earlier infusion studies to elicit experimental mastitis (Moussaoui et al., 2004; Schmitz et al., 2004; Bruckmaier and Meyer, 2005; Haddadi et al., 2006; Boehmer et al., 2008, Danielsen et al., 2010; Wellnitz et al., 2010) and different innate immune responses in bovine mammary cells through differential expression of cytokines were observed (Bannerman et al., 2004; Strandberg et al., 2005).

Mastitis induced by intramammary infusion with gram-negative LPS of $E$. coli resulted in a significant 

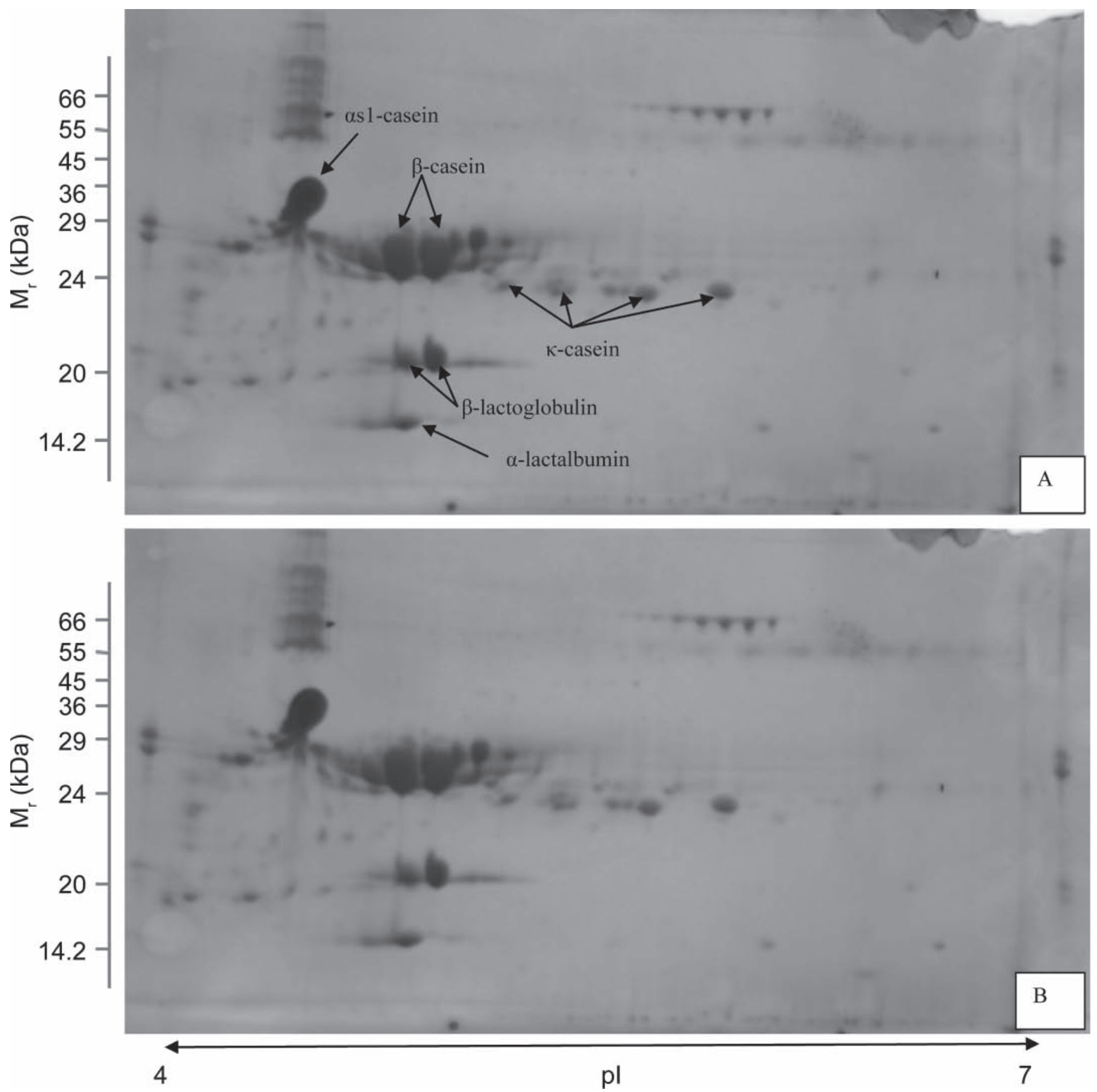

Figure 3. Two-dimensional gel electrophoretograms of milk from A) the control quarter of cow with high LPS (HLPS) 0 h after infusion; B) the infused quarter of cow with HLPS concentration after $0 \mathrm{~h}$. The gels show molecular weights $\left(\mathrm{M}_{\mathrm{r}}\right)$ and isoelectric points (pI) in the range $4-7$.

increase in SCC over time in both cows studied but to a greater extent in the cow infused with HPLS than in the cow infused with LLPS. This is in agreement with other studies of E. coli mastitis (Michelutti et al., 1999; Bannerman et al., 2004; Moussaoui et al., 2004; Haddadi et al., 2006, Wellnitz et al., 2010). Milk SCC is a well-established udder indicator of udder condition and milk quality (O'Brien et al., 2001). Increases in milk SCC can cause an increase in the amount of proteolytic activity and can decrease the yield and quality of dairy products such as cheese. The increased plasmin activity in the milk from infused glands is also consistent 


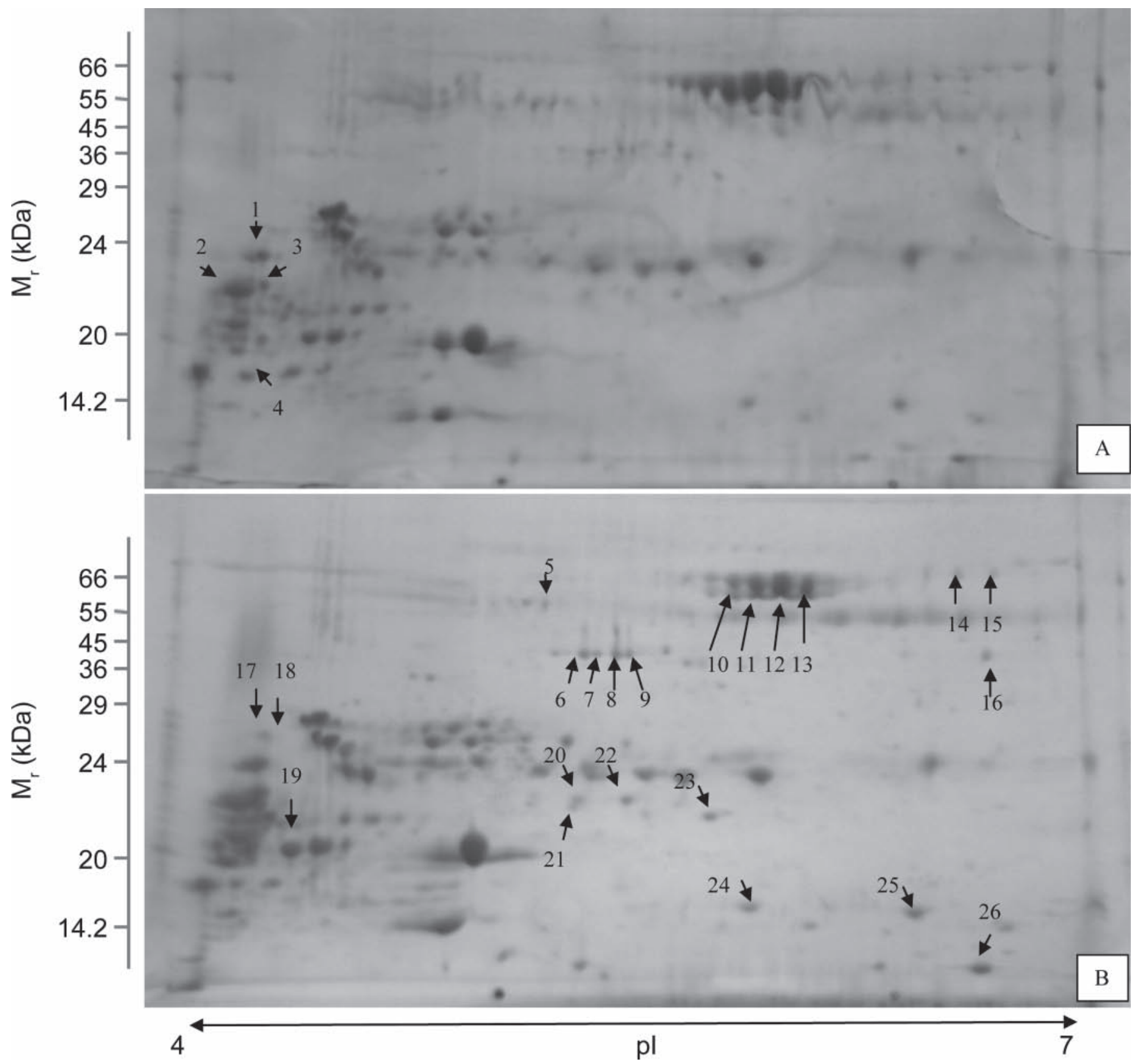

Figure 4. Two-dimensional gel electrophoretograms of milk from A) the infused quarter of cow with high LPS (HLPS) concentration 6 h after infusion and B) the infused quarter of cow with HLPS $12 \mathrm{~h}$ after infusion. The gels show molecular weights $\left(\mathrm{M}_{\mathrm{r}}\right)$ and isoelectric points (pI) in the range 4-7. The gels were stained with Colloid Coomassie Brilliant Blue G-250 (SERVA Electrophoresis GmbH, Heidelberg, Germany) The numbered arrows indicate the 26 spots that were identified by matrix-assisted laser desorption/ionization (MALDI) in Table 3.

with previous results showing activation of the plasmin system during experimentally induced $E$. coli mastitis infections in cows (Grieve and Kitchen, 1985; Saeman et al., 1988; Moussaoui et al., 2002).

Increased proteolysis in milk from infused quarters was also studied using urea PAGE. The proteolysis pattern of the milk from the control quarter of the cow with HLPS sampled at 0 and $6 \mathrm{~h}$ after infusion showed only little hydrolysis of $\alpha_{\mathrm{s} 1}$-and $\beta$-CN during incubation at $37^{\circ} \mathrm{C}$, which is in agreement with previous reports for good quality milk (Kelly and McSweeney, 2003; Schroeder et al., 2008). In contrast, electrophoretograms of the milk from the infected quarter sampled after $6 \mathrm{~h}$ and then incubated at $37^{\circ} \mathrm{C}$ showed complete hydrolysis 
Table 3. Identification of the 26 most abundant spots from the 2-dimensional (2-DE) gel of mastitis milk (Figures 4A and 4B) by peptide mass fingerprinting using matrix-assisted laser desorption/ionization time-of-flight mass spectrometry (MALDI-TOF MS) ${ }^{1}$

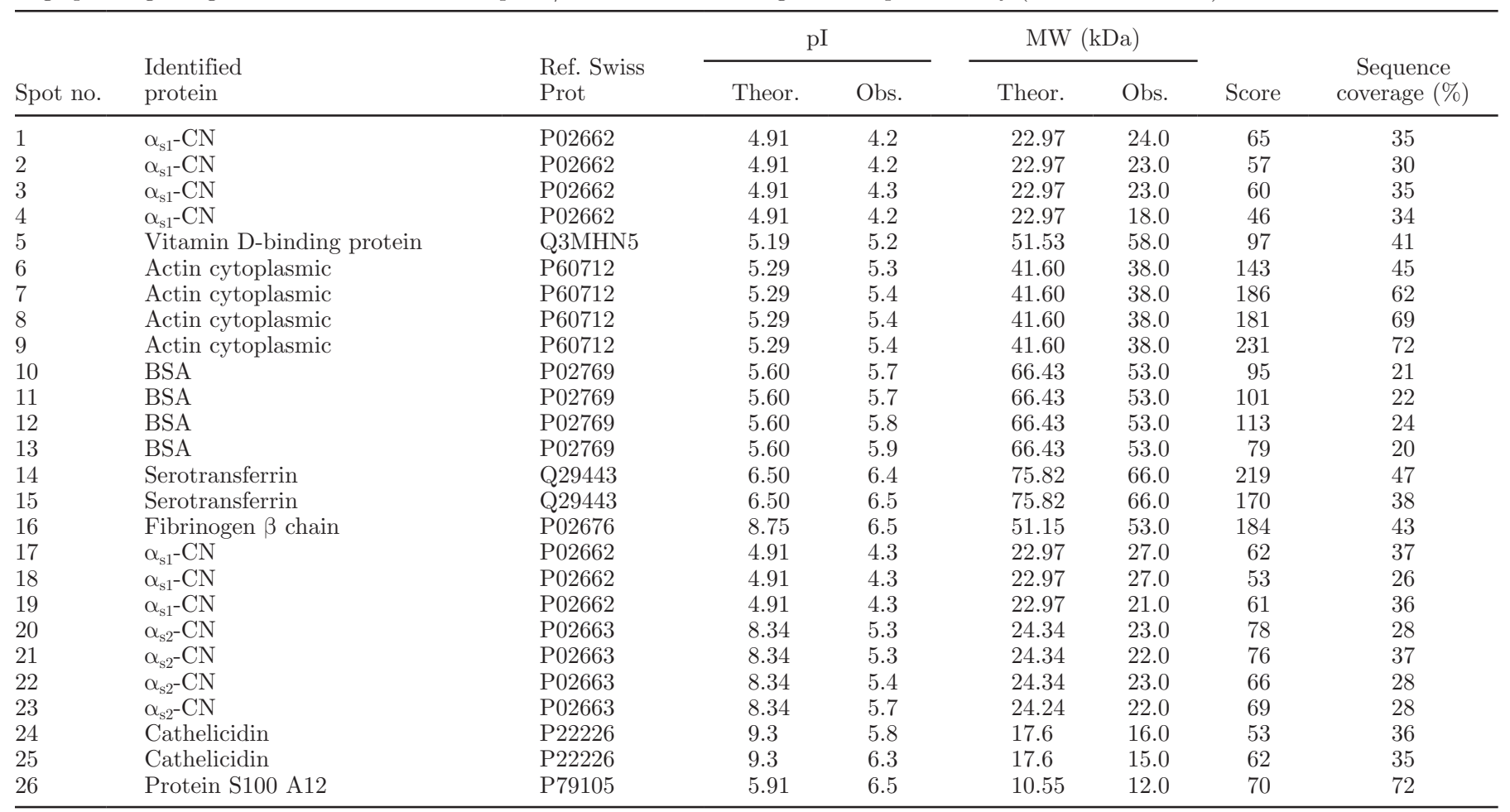

${ }^{1}$ Protein reference (Ref.) corresponds to the Swiss Prot accession number from the Swiss Prot database (Swiss Institute of Bioinformatics, Geneva, Switzerland); theoretical (Theor.) molecular mass and isoelectric point (pI) of proteins are as according to the amino acid primary sequence and without consideration of any post-translational or degradation modifications. Observed (Obs.) molecular mass and pI are as observed with the position of the corresponding spots on the 2-DE electrophoresis gel.

of $\alpha_{\mathrm{S1}^{-}}$and $\beta$-CN. This initial phase of extensive proteolysis of $\beta-\mathrm{CN}$ was in agreement with increased plasmin activity, whereas the proteolysis of $\alpha_{\mathrm{s} 1}-\mathrm{CN}$ could be due to both plasmin activity and enzymes from somatic cells. Urea PAGE electrophoretograms of the control quarter of the cow infused with LLPS showed only little hydrolysis over incubation, whereas milk from the infused quarter after $6 \mathrm{~h}$ and incubated at $37^{\circ} \mathrm{C}$ after $7 \mathrm{~d}$ showed hydrolysis of $\alpha_{\mathrm{S}^{-}}$and $\beta$-CN, resulting in new bands appearing on the gels, but to a lesser extent than in milk from the cow infused with HLPS. Other studies have also detected protein fragments resulting from hydrolysis, mainly from $\alpha_{\mathrm{s}^{-}}$and $\beta-\mathrm{CN}$ (Ballou et al., 1995; Le Roux et al., 1995; Aslam and Hurley 1997; Urech et al., 1999; Moussaoui et al., 2002).

Results of the 2-DE gels demonstrate that exposure to LPS profoundly alters milk protein profiles. Protein patterns after 6 and $12 \mathrm{~h}$ of infusion with LPS showed an increase in hydrolysis of $\alpha_{\mathrm{s} 1^{-}}$and $\alpha_{\mathrm{s} 2}$-CN. Results of other studies (Saeman et al., 1988; Le Roux et al.,1995; Somers et al., 2003; Wedholm et al., 2008a; Larsen et al., 2010) have indicated that the hydrolyses of casein in milk from cows with mastitis, was not exclusively linked to the enzyme plasmin. These studies concluded that proteinases from somatic cells and from blood may also be responsible for some hydrolysis of casein in the milk from cows with mastitis. The main physiological role of somatic cells of the udder is to protect from infection. This is achieved by the release of active proteolytic enzymes from lysosomes of these cells (Kelly and McSweeney, 2003). A rapid increase in proteolytic activity in quarters injected with LPS after 6 and $12 \mathrm{~h}$ resulted in an increase in plasmin activity and was associated with the migration of polymorphonuclear neutrophils (PMN) from blood into the milk component (Mignatti and Rifkin, 1993), resulting in the release of many proteolytic enzymes (e.g., elastase and cathepsins). These proteolytic enzymes damage the blood-milk barrier. Plasmin, elastase, and cathepsins have all been shown to be able to degrade extracellular matrix glycoproteins (Bonnefoy and Legrand, 2000). Elastase and cathepsins have also been found to exhibit proteolytic activity toward bovine casein (Considine et al., 2004). Other LPS-induced mastitis studies showed that neutral proteinase activity was associated with immature PMN, the major somatic cell type in early inflammation (Saad and Östensson, 1990), whereas acidic proteinase activities, which could be cathepsins, were associated 

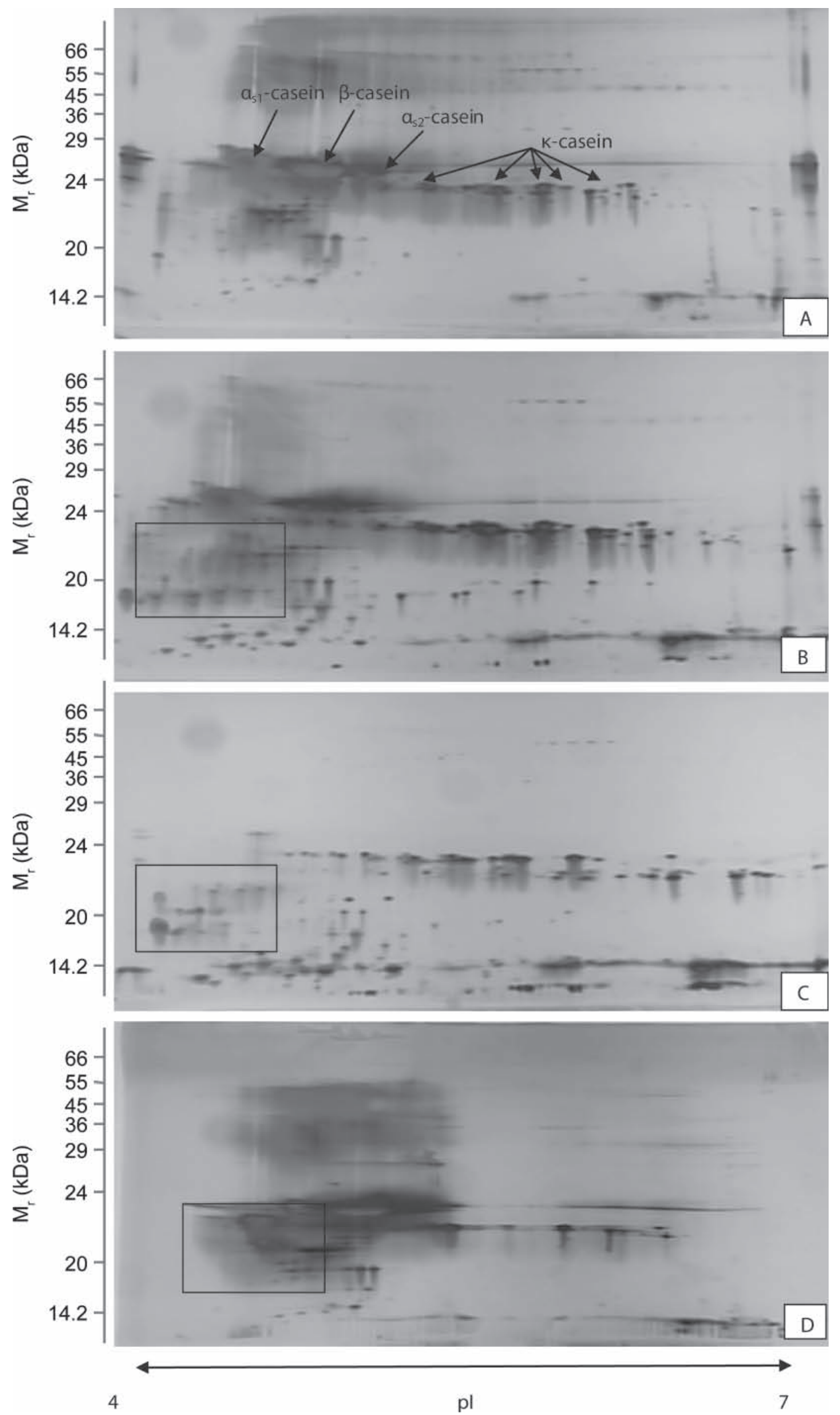

Figure 5. Two-dimensional gel electrophoretograms of model studies of casein digested after 0 (A), 6 (B), or $24 \mathrm{~h}$ (C and D) by plasmin $(\mathrm{B}, \mathrm{C})$ or cathepsin D (D). The gels were silver stained, and the isoelectric point (pI) range was 4-7. The boxes indicate regions of particulate appearance of new spots in the $\alpha_{S 1}$-degradation zone. The positions of the intact caseins are indicated in $(A)$. $\mathrm{M}_{\mathrm{r}}=$ molecular weight. 
with mature PMN (Moussaoui et al., 2002). Some of the proteolysis products were subsequently identified in such studies, and comprised fragments of all 4 caseins produced by somatic cell proteases (Moussaoui et al., 2004). Enzyme activities associated with the PMN were later measured as elastase, collagenase, and cathepsins (Haddadi et al., 2006).

The model studies carried out confirmed that plasmin as expected, extensively hydrolyzed $\beta$ - and $\alpha_{\mathrm{s}}-\mathrm{CN}$, whereas $\kappa-\mathrm{CN}$ was more resistant, though still cleaved to some extent. The amount of plasmin added in the present model study was $0.1 \mathrm{mg} / \mathrm{mL}$, which is approximately 50 times above the level in good-quality milk with low SCC (i.e., 1-2 $\mu \mathrm{g} / \mathrm{mL}$; Benfeldt et al., 1995), although in high-SCC milk, plasmin content is elevated. Furthermore, the $\mathrm{pH}$ used in the model studies, corresponding to the $\mathrm{pH}$ of normal milk (6.7-6.8), is more in favor of plasmin activity than that of cathepsin D, which has a lower $\mathrm{pH}$ optimum (Hurley et al., 2000). However, cathepsin D still was able to hydrolyze the casein to a significant extent at the conditions applied, which corresponded to a significantly higher level of cathepsin D (in the range of 250 fold) than that present in normal milk with low SCC, which has been reported to be around $0.4 \mu \mathrm{g} / \mathrm{mL}$ in skim milk, although it is also elevated at elevated SCC (Hurley et al., 2000).

The appearance of BSA, serotransferrin, fibrinogen $\beta$ chain, vitamin D-binding protein, and cytoplasmic actin in relatively high abundance shown on the 2-DE gels of milk quarters infused with LPS supports the leakage of serum proteins into milk after cytokine production and altered vascular permeability of the mammary epithelium and these proteins are apparently related to the host response. Bovine serum albumin, serotransferrin, and fibrinogen have been identified previously in whey from mastitic milk (Hogarth et al., 2004; Smolenski et al., 2007; Boehmer et al., 2008). Bovine serum albumin was detected in both control and infused milk quarter samples, but in the current study, multiple forms BSA were detected in the milk of infused quarters after 6 and $12 \mathrm{~h}$. Boehmer et al. (2008) also found multiple isoforms of BSA in mastitic whey.

The presence of bovine AMP in the milk of a cow infected with LPS from gram-negative $E$. coli is evidence for neutrophils in the mammary gland (Saad and Östensson, 1990). The cytoplasmic granules of circulating neutrophils are a well-characterized source of AMP belonging to the cathelicidin family, which are released upon neutrophil degranulation in the mammary gland (Tomasinsig and Zanetti, 2005). Studies on the cathelicidin family of peptides have suggested that these peptides can neutralize endotoxins and can suppress the proinflammatory cytokine levels (Scott et al., 2002; Wiese et al., 2003; Zanetti, 2004; Smolenski et al.,
2007; Boehmer et al., 2008; Boehmer et al., 2010).. The presence of the cathelicidin AMP family in bovine milk from cows with mastitis is evidence for the proposal that AMP acts as a defense in the host mechanism. This has previously been reported by Boehmer et al. (2008) and Danielsen et al. (2010).

As this is a model study with a small number of cows, care must be taken in extrapolating the data, but the results still represent a useful contribution to understanding in detail the response of cows to LPS. However, further peptidomic studies of samples obtained from different cows or at other time points may be required to determine, in particular, cow-cow variation in response to such stresses.

\section{ACKNOWLEDGMENTS}

The authors thank the excellent technical assistance of Stina G. Handberg and Hanne S. Møller, Aarhus University, Tjele, Denmark.

\section{REFERENCES}

Andrews, A. T. 1983. Breakdown of caseins by proteinases in bovine milks with high somatic cell counts arising from mastitis or infusion with bacterial endotoxin. J. Dairy Res. 50:57-66.

Aslam, M., and W. L. Hurley. 1997. Proteolysis of milk proteins during involution of the bovine mammary gland. J. Dairy Sci. 80:20042010.

Auldist, M. J., and I. B. Hubble. 1998. Effects of mastitis on raw milk and dairy products. Aust. J. Dairy Technol. 53:269-280.

Ballou, L. U., M. Pasquini, and L. R. D. Bremel. 1995. Factors affecting herd milk composition and milk plasmin at four levels of somatic cell counts. J. Dairy Sci. 78:2186-2195.

Bannerman, D. D., M. J. Paape, W. R. Hare, and E. J. Sohn. 2003. Increased levels of LPS-binding protein in bovine blood and milk following bacterial lipopolysaccharide challenge. J. Dairy Sci. $86: 3128-3137$.

Bannerman, D. D., M. J. Paape, J. W. Lee, X. Zhao, J. C. Hope, and P. Rainard. 2004. Escherichia coli and Staphylococcus aureus elicit differential innate immune responses following intramammary infection. Clin. Diagn. Lab. Immunol. 11:463-472.

Benfeldt, C., L. B. Larsen, J. T. Rasmussen, P. A. Andreasen, and T. E. Petersen. 1995. Isolation and characterization of plasminogen and plasmin from bovine milk. Int. Dairy J. 5:577-592.

Boehmer, J. L., D. D. Bannerman, K. Shefcheck, and J. L. Ward. 2008. Proteomic analysis of differentially expressed proteins in bovine milk during experimentally induced Escherichia coli mastitis. J. Dairy Sci. 91:4206-4218.

Boehmer, J. L., J. L. Ward, R. R. Peters, K. J. Shefcheck, M. A. McFarland, and D. D. Bannerman. 2010. Proteomic analysis of the temporal expression of bovine milk proteins during coliform mastitis and label-free relative quantification. J. Dairy Sci. 93:593-603.

Bonnefoy, A., and C. Legrand. 2000. Proteolysis of subendothelial adhesive glycoproteins (fibronectin, thrombospondin, and von Willebrand factor) by plasmin, leukocyte cathepsin G, and elastase. Thromb. Res. 98:323-332.

Bruckmaier, R. M., and H. H. D. Meyer. 2005. Immunomediator and milk protein gene expression in mammary tissue during endotoxininduced mastitis. Livest. Prod. Sci. 98:81-87.

Considine, T., Á. Healy, A. L. Kelly, and P. L. H. McSweeney. 2004. Hydrolysis of bovine caseins by cathepsin B, a cysteine proteinase indigenous to milk. Int. Dairy J. 14:117-124.

Danielsen, M., M. C. Codrea, K. L. Ingvartsen, N. C. Friggens, E. Bendixen, and C. M. Røntved. 2010. Quantitative milk proteomics- 
Host responses to lipopolysaccharide-mediated inflammation of bovine mammary gland. Proteomics 10:2240-2249.

de Rham, O., and A. T. Andrews. 1982. Qualitative and quantitative determination of proteolysis in mastitis milk. J. Dairy Res. 49:587-596.

Eberhart, R. J., R. J. Harmon, D. E. Jasper, R. P. Natzke, S. C. Nickerson, J. K. Reneau, E. H. Row, K. L. Smith, and S. B. Spencer. 1987. Current Concepts of Bovine Mastitis. 3rd ed. National Mastitis Council Inc., Arlington, VA.

Gagnaire, V., D. Mollé, M. Herrouin, and J. Léonil. 2001. Peptides identified during Emmental cheese ripening: Origin and proteolytic systems involved. J. Agric. Food Chem. 49:4402-4413.

Grieve, P. A., and B. J. Kitchen. 1985. Proteolysis in milk: The significance of proteinases originating from milk leucocytes and a comparison of the action of leucocytes, bacterial and natural milk proteinases on casein. J. Dairy Res. 52:101-112.

Haddadi, K., C. Prin-Mathieu, F. Moussaoui, G. C. Faure, F. Vangroenweghe, C. Burvenich, and Y. Le Roux. 2006. Polymorphonuclear neutrophils and Escherichia coli proteases involved in proteolysis of casein during experimental E. coli mastitis. Int. Dairy J. 16:639-647.

Heegaard, C. W., T. Christensen, M. D. Rasmussen, C. Benfeldt, N. E. Jensen, K. Sejrsen, T. E. Petersen, and P. A. Andreasen. 1994. Plasminogen activators in bovine milk during mastitis, an inflammatory disease. Fibrinolysis 8:22-30.

Hirvonen, J., K. Eklund, A. M. Teppo, G. Huszenicza, M. Kulcsar, H. Saloniemi, and S. Pyörälä. 1999. Acute phase response in dairy cows with experimentally induced Escherichia coli mastitis. Acta Vet. Scand. 40:35-46.

Hogan, J. S., W. P. Weiss, D. A. Todhunter, K. L. Smith, and P. S. Schoenberger. 1992. Efficacy of an Escherichia coli J5 mastitis vaccine in an experimental challenge trial. J. Dairy Sci. 75:415-422.

Hogarth, C. J., J. L. Fitzpatrick, A. M. Nolan, F. J. Young, A. Pitt, and P. D. Eckersall. 2004. Differential protein composition of bovine whey: A comparison of whey from healthy animals and from those with clinical mastitis. Proteomics 4:2094-2100.

Hurley, M. J., L. B. Larsen, A. L. Kelly, and P. L. H. McSweeney 2000. The milk acid proteinase cathepsin D: A review. Int. Dairy J. 10:673-681

Jackson, K. W., N. Esmon, and J. Tang. 1981. Streptokinase and staphylokinase. Methods Enzymol. 80:387-394.

Kelly, A. L., F. O'Flaherty, and P. F. Fox. 2006. Indigenous proteolytic enzymes in milk: A brief overview of the present stage of knowledge. Int. Dairy J. 16:563-572.

Kelly, A. L., and P. L. H. McSweeney. 2003. Indigenous proteolytic enzymes in milk. Pages 495-544 in Advanced Dairy Chemistry: Volume I: Proteins. 3rd ed. P. F. Fox and P. L. H. McSweeney, ed. Kluwer Academic-Plenum Publishers, New York, NY.

Kirschke, H., and A. J. Barrett. 1987. Chemistry of lysosomal proteases. Pages 193-238 in Lysosomes, Their role in Protein Breakdown. H. Glaumann and F. J. Ballard, ed. Academic press, New York, NY.

Larsen, L. B., K. Hinz, A. L. W. Jørgensen, H. S. Møller, O. Wellnitz, R. M. Bruckmaier, and A. L. Kelly. 2010. Proteomic and peptidomic study of proteolysis in quarter milk after infusion with lipoteichoic acid from Staphylococcus aureus. J. Dairy Sci. 93:5613-5626.

Larsen, L. B., P. L. H. McSweeney, M. G. Hayes, J. B. Andersen, K. L. Ingvartsen, and A. L. Kelly. 2006. Variation in activity and heterogeneity of bovine milk proteases with stage of lactation and somatic cell count. Int. Dairy J. 16:1-8.

Larsen, L. B., M. D. Rasmussen, M. Bjerring, and J. H. Nielsen. 2004 Proteases and protein degradation in milk from cows infected with Streptococcus uberis. Int. Dairy J. 14:899-907.

Le Roux, Y., O. Colin, and F. Laurent. 1995. Proteolysis in samples of quarter milk with varying somatic cell count. 1. Comparison of some indicators of endogenous proteolysis in milk. J. Dairy Sci. 78:1289-1297.

Leigh, J. A. 1999. Streptococcus uberis: A permanent barrier to the control of bovine mastitis. Vet. J. 157:225-238.
Michelutti, I., Y. Le Roux, P. Rainard, B. Poutrel, and F. Laurent. 1999. Sequential changes in milk protein composition after experimental Escherichia coli mastitis. Lait 79:535-549.

Mignatti, P., and D. B. Rifkin. 1993. Biology and biochemistry of proteinases in tumor invasion. Physiol. Rev. 73:161-195.

Moussaoui, F., I. Michelutti, Y. Le Roux, and F. Laurent. 2002. Mechanisms involved in milk endogenous proteolysis induced by a lipopolysaccharide experimental mastitis 2002. J. Dairy Sci $85: 2562-2570$

Moussaoui, F., F. Vangroenweghe, K. Haddadi, Y. Le Roux, F. Laurent, L. Duchateau, and C. Burvenich. 2004. Proteolysis in milk during experimental Escherichia coli mastitis. J. Dairy Sci. 87:2923-2931.

O'Brien, B., W. J. Meaney, D. McDonagh, and A. L. Kelly. 2001. Influence of somatic cell count and storage interval on composition and processing characteristics of milk from cows in late lactation. Aust. J. Dairy Technol. 56:213-218.

Politis, I., E. Lachance, E. Block, and J. D. Turner. 1989. Plasmin and plasminogen in bovine milk: A relationship with involution? J. Dairy Sci. 72:900-906.

Saad, A. M., and K. Östensson. 1990. Flow cytofluorometric studies on the alteration of leukocyte populations in blood and milk during endotoxin-induced mastitis in cows. Am. J. Vet. Res. 51:16031607.

Saeman, A. I., R. J. Verdi, D. M. Galton, and D. M. Barbano. 1988. Effect of mastitis on proteolytic activity of bovine milk. J. Dairy Sci. 71:505-512.

Schalm, O. W., and G. Ziv-Silberman. 1968. Reactions following intramammary infusion of E. coli endotoxin. Vet. Rec. 82:100-103.

Schmitz, S., M. W. Pfaffl, H. H. Meyer, and R. M. Bruckmaier. 2004. Short-term changes of mRNA expression of various inflammatory factors and milk proteins in mammary tissue during LPS-induced mastitis. Domest. Anim. Endocrinol. 26:111-126.

Schroeder, D. L., S. S. Nielsen, and K. D. Hayes. 2008. The effect of raw milk storage temperature on plasmin activity and plasminogen activation in pasteurized milk. Int. Dairy J. 18:114-119.

Scott, M. G., D. J. Davidson, M. R. Gold, D. Bowdish, and R. E. Hancock. 2002. The human antimicrobial peptide LL-37 is a multifunctional modulator of innate immune responses. J. Immunol. 169:3883-3891.

Shim, E. H., R. D. Shanks, and D. E. Morin. 2004. Milk loss and treatment costs associated with two treatment protocols for clinical mastitis in dairy cows. J. Dairy Sci. 87:2702-2708.

Sládek, Z., D. Rysánek, and M. Faldyna. 2002. Activation of phagocytes during initiation and resolution of mammary gland injury induced by lip polysaccharide in heifers. Vet. Res. 33:191-204.

Smolenski, G., S. Haines, F. Y.-S. Kwan, J. Bond, V. Farr, S. R. Davis, K. Stelwagen, and T. T. Wheeler. 2007. Characterisation of host defence proteins in milk using a proteomic approach. J. Proteome Res. 6:207-215.

Sohn, E. J., M. J. Paape, E. E. Connor, D. D. Bannerman, R. H. Fetterer, and P. R. Peters. 2007. Bacterial lipopolysaccharide stimulates bovine neutrophil production of TNF- $\alpha$, Il-1 $\beta$, IL-12 and IFN- $\gamma$. Vet. Res. 38:809-818.

Somers, J. M., B. O'Brien, W. J. Meaney, and A. L. Kelly. 2003. Heterogeneity of proteolytic enzyme activities in milk samples of different somatic cell count. J. Dairy Res. 70:45-50.

Sordillo, L. M., K. Shafer-Weaver, and D. DeRosa. 1997. Immunobiology of the mammary gland. J. Dairy Sci. 80:1851-1865.

Strandberg, Y., C. Gray, T. Vuocolo, L. Donaldson, M. Broadway, and R. Tellam. 2005. Lipopolysaccharide and lipotheichoic induce different immune responses in bovine mammary epithelial cells. Cytokine 31:72-86.

Tomasinsig, L., and M. Zanetti. 2005. The cathelicidins-Structure, function and evolution. Curr. Protein Pept. Sci. 6:23-34.

Travis, J. 1988. Structure, function and control of neutrophil proteinases. Am. J. Med. 84:37-42.

Urech, E., Z. Puhan, and M. Schällibaum. 1999. Changes in milk protein fraction as affected by subclinical mastitis. J. Dairy Sci. $82: 2402-2411$. 
Wedholm, A., H. S. Møller, H. Lindmark-Månsson, M. D. Rasmussen, A. Andrén, and L. B. Larsen. 2008a. Identification of peptides in milk as a result of proteolysis at different levels of somatic cell counts using LC MALDI MS/MS detection. J. Dairy Res. 75:76-83.

Wedholm, A., H. S. Møller, A. Stensballe, H. Lindmark-Månsson, A H. Karlsson, R. Andersson, A. Andrén, and L. B. Larsen. 2008b. Effect of milk protein composition on cheese yield and quality as determined by proteomics and multivariate data analysis. J. Dairy Sci. 91:3787-3797.

Wellnitz, O., A. Baumert, M. Saudenowa, and R. M. Bruckmaier. 2010. Immune response of bovine milk somatic cells to endotoxin in healthy quarters with normal and very low cell counts. J. Dairy Res. 77:452-459.

Wiese, A., T. Gutsmann, and U. Seydel. 2003. Towards antibacterial strategies: Studies on the mechanisms of interaction between antibacterial peptides and model membranes. J. Endotoxin Res. 9:67-84.

Wium, H., K. R. Kristiansen, and K. B. Qvist. 1998. Proteolysis and its role in relation to texture of Feta cheese made from ultrafiltered milk with different amounts of rennet. J. Dairy Res. 65:665-674.

Yang, W., H. Zerbe, W. Petzl, R. M. Brunner, J. Günther, C. Draing, S. von Aulock, H.-J. Schuberth, and H.-M. Seyfert. 2008. Bovine TLR2 and TLR4 properly transduce signals from Staphylococcus aureus and $E$. coli, but $S$. aureus fails to both activate NF- $\kappa$ B in mammary epithelial cells and to quickly induce TNF $\alpha$ and interleukin-8 (CXCL8) expression in the udder. Mol. Immunol. 45:1385-1397.

Zanetti, M. 2004. Cathelicidins, multifunctional peptides of the innate immunity. J. Leukoc. Biol. 75:39-48. 